\title{
Kondisi Terumbu Karang Di Perairan Pantai Empu Rancak, Mlonggo, Kabupaten Jepara
}

\author{
Suryono, Edi Wibowo, Raden Ario, Nur Taufik S.P.J. dan Ria Azizah Tri Nuraini \\ Departemen IImu Kelautan, Fakultas Perikanan dan IImu Kelautan, Universitas Diponegoro \\ JI. Prof. H. Soedharto, SH, Tembalang Semarang. 50275 \\ Email : suryono1960@gmail.com
}

\section{Abstract \\ Coral Reef Condition In Coastal Waters of Empu Rancak, Mlonggo, Regency of Jepara}

Empu Rancak coastal waters in Karanggondang village, Mlonggo District is one of the coral reef ecosystem location in coastal area of Jepara Regency. Following the growth of culinary and Marine tourism bring the need for monitoring the condition of coral reefs so that such activity does not provide ecological impacts against the condition of coral reefs. The method used to assess the condition of coral reefs is Line Intercept Transect which done by percentage calculation of living coral coverage. The research results shows that the condition of the coral reefs in a depth of 3 metres found coral cover percentage of $4.5 \%$, while at a depth of 6 meters found coral cover percentage of $9.7 \%$. From this result indicates the coral reefs in critical condition, however the high biodiversity and dominance index value is presumed that these coral reefs was in good condition. It's showed by the high percentage of coral die either at a depth of 3 metres (95.54\%) or at a depth of 6 meters(90.30\%). The diversity of species of coral were found at a depth of 3 meters consist of 6 genus, they are: Goniastrea sp., Favia sp., Galaxea sp., Porites, Acropora sp. and Montipora sp., whereas at a depth of 6 meters were found more species of coral diversity for at least 11 genus, they are: Acropora sp., Favites sp., Echinopora sp., Goniastrea sp. Symphyllia agaricia sp, Favia sp., Goniopora sp., Porites sp., Montipora sp., Platygyra sp., and Montastrea sp. The condition of coral reefs cover which relatively critical are caused by decreasing the quality of waters ecology that caused by sedimentation rate and runoff processes of land activity, high waves in northwest monsoon and the growth of culinary tourism as well as marine tourism in Empu Rancak coastal waters gradually worsen the condition of coral reefs.

Keywords : Coral reef, tourism, Line Intercept Transect,

\section{Abstrak}

Perairan pantai Empu Rancak desa Karanggondang, Kecamatan Mlonggo merupakan salah satu lokasi ekosistem terumbu karang yang berada pesisir di kabupaten Jepara. Dengan berkembangnya aktivitas wisata kuliner serta wisata bahari, maka perlu dilakukan pemantauan kondisi terumbu karang agar kegiatan tersebut tidak tidak memberikan dampak ekologi terhadap kondisi terumbu karang. Metode yang dipergunakan untuk menilai kondisi terumbu karang adalah dengan metode perhitungan persentase penutupan karang hidup menggunakan Line Intercept Transect. Hasil penelitian menunjukan bahwa Kondisi terumbu karang di kedalaman 3 meter ditemukan prosentasi tutupan karang sebesar 4,5\%, sedangkan pada kedalaman 6 meter ditemukan prosentase tutupan karang sebesar $9,7 \%$, maka kondisi terumbu karang di perairan pantai empu rancak Mlonggo, dalam kondisi buruk sekali, namun tingginya keanekaragaman dan nilai indeks dominasi, maka diduga bahwa terumbu karang dilokasi penelitian pernah dalam kondisi baik sebelumnya. Hal ini ditunjukan dengan tingginya prosentase karang mati baik pada kedalaman 3 meter (95,54\%) maupun pada kedalaman 6 meter (90,30 \%). Keanekaragaman jenis karang yang ditemukan pada kedalaman 3 meter terdiri atas 6 genus yaitu : GoniastreaSp., Favia Sp., Galaxea Sp., Porites Sp., Acropora Sp., dan Montipora Sp.,sedangkan pada kedalaman 6 meter ditemukan keanekaraamanan jenis karang yang lebih banyak (11 genus), yaitu : Acropora 
sp., Favites sp., Echinopora sp., Goniastrea sp., Symphyllia agaricia, Favia sp., Goniopora sp., Porites sp., Montipora sp., Platygyra sp. , dan Montastrea sp. Kondisi tutupan terumbu karang yang relatif buruk sekali diduga diakibatkan oleh menurunnya kualitas ekologi perairan yang diakibatkan oleh oleh tekanan laju sedimentasi serta proses run off dari aktivitas didaratan, tingginya paparan gelombang pada saat musim barat serta berkembangnya wisata kuliner serta wisata bahari di perairan Pantai Empu rancak yang memperburuk kondisi terumbu karang.

Kata Kunci : Terumbu Karang, pariwisata, Line Intercept Transect

\section{PENDAHULUAN}

Terumbu karang merupakan ekosistem penting bagi keberlanjutan sumberdaya wilayah pesisir. Secara ekologi, ekosistem terumbu karang berfungsi sebagai penyangga bagi kehidupan biota pesisir dan lautan (Bengen, 2002). Terumbu karang memiliki peranan yang sangat penting, baik dilihat dari sisi manusia maupun keanekaragaman dan keberlanjutan biota laut.(Licuanan et al., 2016 dan Hapsari et al., 2017). Selanjutnya Sutono (2016), mengatakan bahwa Ekosistem terumbu karang merupakan kekayaan sumberdaya laut yang memiliki beberapa peranan penting dalam mendukung kehidupan berbagai organisme perairan, diantaranya adalah sebagai tempat tinggal, tempat mencari makan, tempat berlindung dan tempat berkembang biak bagi sebagian besar biota laut. Keberadaan terumbu karang berperan sebagai pelindung pantai dari abrasi akibat terpaan arus, angin, dan gelombang. Secara ekonomi, ekosistem terumbu memiliki potensi dan produksi ekonomi yang tinggi, dikarenakan Terumbu karang merupakan kawasan panorama bawah laut yang sangat indah, dan berpotensi dalam pengembangan sektor pariwisata bahari. (Umar, 2011; Wahyudin, 2011)

Namun kondisi sekarang, ekosistem terumbu karang telah mengalami perubahan dalam skala global yang diakibatkan oleh perubahan iklim serta oleh aktivitas manusia (Lasagna et al, 2014). Berdasarkan data yang dipublikasi oleh Global Coral Reef Monitoring Network (GCMRN) tahun 2008, kurang lebih $54 \%$ terumbu karang dunia berada dalam kondisi terancam secara global (Wilkinson, 2008). Yusuf (2013), mengatakan bahwa kerusakan terumbu karang di Indonesia lebih banyak disebabkan oleh berbagai kegiatan manusia dalam pemanfaatan sumber daya laut. Ekosistem terumbu karang merupakan salah satu ekosistem yang rapuh sehingga tergolong ke dalam ekosistem yang laju kepunahannya relatif cepat bila mendapat gangguan. Ekosistem terumbu karang merupakan sumberdaya wilayah pesisir yang sangat rentan terhadap kerusakan, terutama yang disebabkan oleh perilaku manusia/masyarakat disekitarnya. (Rauf dan Yusuf, 2004; Tonin, 2018).

Kabupaten Jepara memiliki berberapa lokasi gugusan terumbu karang, salah satunya adalah yang berada di Perairan pantai Empu Rancak desa Karang Gondang, Kecamatan Mlonggo. Lokasi tersebut telah berkembang menjadi destinasi wisata kuliner dan wisata pantai pada lima tahun terakir. Oleh karena itu maka perlu dilakukan pemantauan kondisi terumbu karang sebagai basis data guna perencanaan dalam pengelolaan wilayah pesisir secara terpadu. Tujuan penelitian ini adalah untuk mengetahui kondisi terumbu karang dengan melihat persentase tutupan karang hidup yang ada.

\section{MATERI DAN METODE}

Pada survey pendahuluan di tentukan di enam stasiun yaitu pada kedalaman 3 meter, 4 meter, 5 meter, 6 meter dan di kedalaman 10 meter (Gambar 1.) Lokasi pengamatan terumbu karang di Pantai Empu Rancak dimulai dari ujung selatan sepanjang 50 meter dilanjutkan pada sisi tengah pantai sepanjang 50 meter, serta sisi utara pantai sepanjang 50 meter.

Pengumpulan data tutupan karang hidup dilakukan dengan metode line intercept transect modifikasi (English et al., 
1994). Penutupan karang hidup diketahui dengan menggunakan transek garis menyinggung (Line Intercept Transect). Transek garis sepanjang $50 \mathrm{~m}$ dibentangkan pada setiap stasiun di perairan Empu Rancak Desa Karang Gondang Kecamaatan Mlonggo pada 3 Stasiun hasil studi pendahuluan. Selanjutnya dilakukan pencatatan tutupan karang dan biota yang berasosiasi dengan karang yang terdapat di bawah meteran hingga ketelitian $\mathrm{cm}$. Setiap koloni karang yang ditemukan berada di bawah transek diidentifikasi hingga tingkat genus.

Data yang diperoleh dianalisa menggunakan metode deskriptif yaitu dengan menggambarkan hasil yang telah diperoleh dan didukung dengan membandingkan tabulasi dari pengolahan data. Perhitungan mengenai persentase karang hidup juga dilakukan untuk menentukan kondisi terumbu karang di daerah tersebut (Fahcrul, 2007). Persentase penutupan karang hidup dihitung berdasarkan persamaan yang dikemukakan Englist et al. (1994).

\section{HASIL DAN PEMBAHASAN}

Hasil pengamatan kondisi terumbu karang hidup dapat dilihat pada Tabel 1. Pada kedalaman 3 meter ditemukan prosentase tutupan karang sebesar 4,5\%, sedangkan pada kedalaman 6 meter ditemukan prosentase tutupan karang sebesar 9,7 \%. Dilihat dari besarnya prosentase tutupan karang di perairan Empu Rancak Mlonggo Kabupaten Jepara dapat dikatakan bahwa kondisi terumbu karang dalam buruk sekali. Hal ini sesuai dengan kriteria kondisi terumbu karang yang dikemukakan oleh Gomez dan Yap, 1988, bahwa kondisi terumbu karang dengan prosentasi $0-24 \%$ adalah kondisi terumbu karang dalam kondisi buruk sekali. Apabila persentase tutupan karang berkisar 75-100 \% maka disebut kondisinya baik. Pada kedalaman 3 meter ditemukan keanekaragaman jenis karang sebanyak 6 genus yaitu : Goniastrea sp., Favia Sp., Galaxea sp., Porites sp., Acropora sp., dan Montipora p. (Tabel 1 dan Gambar 2), sedangkan pada kedalaman 6 meter ditemukan keanekaraamanan jenis karang yang lebih banyak, yaitu 11 genus terdiri dari : Acropora sp. , Favites sp, Echinopora sp., Goniastrea sp., Symphyllia agaricia, Favia sp., Goniopora sp., Porites sp., Montipora sp., Platygyra sp., dan Montastrea. sp. (Tabel 2 dan Gambar 3).

Tingginya tingkat kerusakan terumbu karang yang terjadi di perairan pantai Empu Rancak Mlonggo Kabupaten Jepara dapat dilihat dengan tingginya prosentase karang mati, baik pada kedalaman 3 meter sebesar 95,54\% maupun pada kedalaman 6 meter sebesar 90,30 \% (Tabel 1 dan Tabel 2). Namun dari hasil pemantauan menunjukan bahwa ditemukan nilai yang tinggi pada keanekaraman jenis dan indek dominasi karang yang masih hidup. Hal ini mengindikasikan bahwa dilokasi perairan

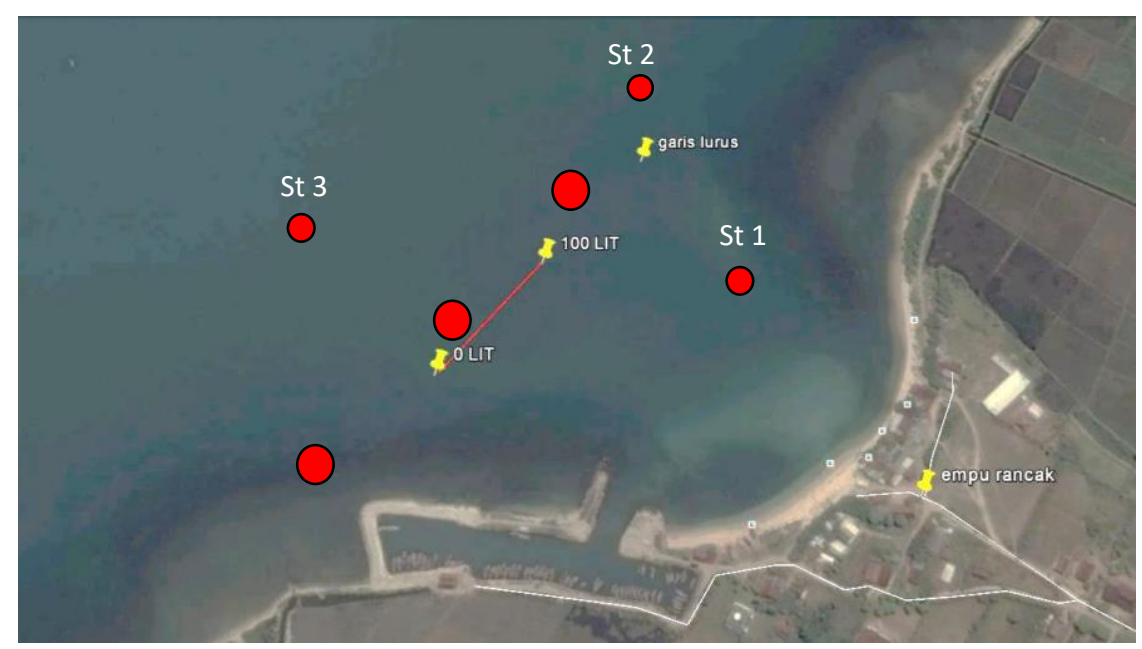

Gambar 1. Lokasi Stasiun Pemantauan Terumbu Karang di Perairan Pantai Empu Rancak 
pantai Empu Rancak Mlonggo Kabupaten Jepara kondisi terumbu karangnya pernah dalam kondisi baik, kemudian mengalami kerusakan beberapa tahun terakhir. Rusaknya terumbu karang yang terjadi diduga dipengaruh gangguan alam serta tekanan oleh aktivitas manusia (Lasagna, 2014 dan Brown et al., 2017). Sedimentasi oleh peristiwa run off daratan melalui aliran sungai yang ada, yaitu sungai Mlonggo, terkena jaring dan jangkar perahu nelayan, pengaruh penyakit karang serta terinjak-injak oleh aktivitas pariwisata diduga sebagai tekanan akibat aktivitas manusia (antrophogenik). Hal itu sesuai dengan penelitian yang dilakukan oleh Hapsari et al. (2017) bahwa rusaknya kondisi terumbu karang Kepulauan Seribu adalah dikarenakan lokasi tersebut digunakan untuk kegiatan pariwisata bawah air. Selanjutnya menurut Yusuf (2013), kerusakan terumbu karang di Indonesia lebih banyak disebabkan

Tabel 1. Tutupan Karang Pada Kedalaman 3 meter di PerairanPantai Empu Rancak, Mlonggo Jepara

\begin{tabular}{|c|c|c|c|c|c|c|}
\hline Genus & li & ni & $\%$ ni & C Dominansi & \% cover & \%karang mati \\
\hline Sand & 7015 & 0,7015 & $70,15 \%$ & 0,49210225 & & $95,54 \%$ \\
\hline Dead Coral Algae & 2273 & 0,2273 & $22,73 \%$ & 0,05166529 & & \\
\hline Dead Coral & 70 & 0,007 & $0,70 \%$ & 0,000049 & & \\
\hline OT(Sponge) & 46 & 0,0046 & $0,46 \%$ & 0,00002116 & & \\
\hline Goniastrea sp. & 114 & 0,0114 & $1,14 \%$ & 0,00012996 & & \\
\hline Favia Sp. & 259 & 0,0259 & $2,59 \%$ & 0,00067081 & & \\
\hline Galaxea Sp. & 32 & 0,0032 & $0,32 \%$ & 0,00001024 & & \\
\hline Porites Sp. & 6 & 0,0006 & $0,06 \%$ & 0,00000036 & & \\
\hline RC(Rock) & 150 & 0,015 & $1,50 \%$ & 0,000225 & & \\
\hline Acropora Sp. & 5 & 0,0005 & $0,05 \%$ & 0,00000025 & & \\
\hline Montipora Sp. & 30 & 0,003 & $0,30 \%$ & 0,000009 & & \\
\hline JUMLAH & 10000 & 1 & $100,00 \%$ & 1 & $4,5 \%$ & $95,5 \%$ \\
\hline
\end{tabular}

Tabel.2. Tutupan Karang Pada Kedalaman 6 meter di Perairan Pantai Empu Rancak, Mlonggo Jepara

\begin{tabular}{lrrrrrr}
\hline \multicolumn{1}{c}{ Genus } & \multicolumn{1}{c}{ li } & \multicolumn{1}{c}{ ni } & \multicolumn{1}{l}{ \%ni } & C Dominansi & \% cover & \%karang mati \\
\hline Sand & 1704 & 0,1704 & $34,08 \%$ & 0,02903616 & & $90,30 \%$ \\
DeadCoral Algae & 2016 & 0,2016 & $40,32 \%$ & 0,04064256 & \\
Non Identified Algae & 795 & 0,0795 & $15,90 \%$ & 0,00632025 & \\
Acropora Sp. & 7 & 0,0007 & $0,14 \%$ & 0,00000049 & \\
Favites Sp. & 87 & 0,0087 & $1,74 \%$ & 0,00007569 & \\
Echinopora Sp. & 8 & 0,0008 & $0,16 \%$ & 0,00000064 & \\
Goniastrea sp. & 108 & 0,0108 & $2,16 \%$ & 0,00011664 & \\
Symphyllia Agaricia & 18 & 0,0018 & $0,36 \%$ & 0,00000324 & \\
Favia Sp. & 116 & 0,0116 & $2,32 \%$ & 0,00013456 & \\
Goniopora Sp. & 36 & 0,0036 & $0,72 \%$ & 0,00001296 & \\
Porites Sp. & 63 & 0,0063 & $1,26 \%$ & 0,00003969 & \\
Montipora Sp. & 10 & 0,001 & $0,20 \%$ & 0,000001 & & \\
Platdentifiedygyra Sp. & 21 & 0,0021 & $0,42 \%$ & 0,00000441 & & \\
Montastrea Sp. & 11 & 0,0011 & $0,22 \%$ & 0,00000121 & \\
JUMLAH & 5000 & 0,5000 & $100,00 \%$ & 0,0763895 & $9,7 \%$ & $90,30 \%$ \\
\hline
\end{tabular}

Keterangan : li : Panjang koloni karang per panjang transek garis $(\mathrm{cm})$

$\mathrm{Ni} \quad$ : Panjang koloni di bagi total panjang transek

\%ni : Persentase penutupan koloni karang (\%)

C Dominasi : Indeks Dominasi 
oleh berbagai kegiatan manusia dalam pemanfaatan sumber daya lautnya. Selain itu, kegiatan pariwisata bawah air dapat berdampak negatif bagi kondisi terumbu karang jika tidak dikelola dengan baik.

Dominasi karang massive (Goniastrea sp., Goniphora sp., Porites dan Favites sp.) menunjukan perairan di lokasi pemantauan mengalami tekanan yang besar. Secara umum karang massive lebih banyak dijumpai di kawasan tersebut dikarenakan koloni karang ini memiliki kemampuan bertahan yang lebih baik terhadaap tekanan ekologi. Run off dari daratan dan resuspensi sedimen diduga menjadi sumber ancaman yang membuat perairan menjadi keruh. Selain membuat keruh sedimentasi memicu meningkatnya kesuburan perairan sehingga terjadi blooming makroalga (Edinger et al., 1998). Pantai Empu Rancak sebagai destinasi wisata sangat rentan terhadap sampah dan limbah domestik rumah tangga/wisata kuliner (Yusuf, 2013 dan Retno et al., 2017).

Secara umum kerusakan terumbu karang diakibatkan oleh sedimentasi dari muara sungai dan resuspensi sedimen pada saat datangnya arus dasar baik pada saat musim timur maupun pada saat musim barat . Kedua faktor tersebut membuat kecerahan perairan di lokasi pengamatan relatif rendah. Perairan yang keruh menyebabkan penetrasi cahaya terdapat pada lokasi yang dangkal saja. Kondisi tersebut mempengaruhi sebaran terumbu karang. Lokasi yang banyak ditemukan karang keras hidup berada di area puncak hingga dataran terumbu. Pertumbuhan alga yang cepat akan menimbulkan kompetisi dengan karang keras hidup. Jika terjadi dalam waktu yang lama akan meningkatkan tutupan karang mati ditumbuhi alga. Selain itu, sampah dari sisa jaring nelayan mengindikasikan lokasi terumbu karang menjadi area penangkapan para nelayan sekitar. Kerusakan terumbu karang yang terjadi di lokasi ini berupa karang mati dari karang massive dan branching. Kerusakan pada karang massive berupa karang mati ditumbuhi alga yang dipicu oleh penyakit karang. Kejadian tersebut diduga diakibatkan oleh menurunnya kualitas perairan akibat sedimentasi. Sedangkan, kerusakan pada karang bercabang (branching) ditemukan berupa pecahan karang (rubble) dari genus Acropora Sp.. Pecahan karang paling banyak ditemukan di dataran terumbu. Kerusakan tersebut diduga diakibatkan oleh aktivitas gelombang musim barat. Selain itu, aktivitas manusia seperti wisata, berenang, memancing ataupun pencari kerang turut serta memicu banyaknya pecahan karang akibat terinjak - injak (gleening).

Tingkat kerusakan karang lunak dalam kategori rendah hingga tinggi yang diakibatkan oleh sedimentasi dan pemutihan karang (bleaching). Kerusakan terumbu karang di lokasi ini ditunjukan oleh rendahnya tutupan karang hidup (Fachrul, 2007; Prasetyo, 2012 dan Brown,2017). Kondisi tersebut sangat jamak terjadi di daerah terumbu karang yang memiliki tekanan yang besar. Berdasarkan hasil wawancara dengan beberapa tokoh masyarakat setempat, diperoleh informasi bahwa pada wilayah perairan tersebut masih ada masyarakat yang menambang batu karang dan pasir laut untuk bahan bangunan, sehingga diduga aktivitas inilah yang memicu kerusakan ekosistem terumbu karang (Prasetia 2012).

\section{KESIMPULAN}

Kondisi terumbu karang di peraiaran Pantai Empu Rancak Mlonggo Kabupaten Jepara pada kondisi buruk sekali. Namun dilihat dari keanekaragaman karang hidup yang ditemukan diduga dahulu pernah dalam kondisi baik, namun telah mengalami degradasi dari segi prosentasi tutupan karang (\% Coral Cover). Kondisi tersebut akibat dari perkembangan wisata kuliner dan wisata bahari di perairan Pantai Empu rancak, sedimentasi serta run off dari daratan.

\section{UCAPAN TERIMA KASIH}

Penelitian ini terselenggara atas dukungan pendanaan APBD Kabupaten Jepara, pada Dinas Kelautan dan Perikanan Kabupaten Jepara.

\section{DAFTAR PUSTAKA}

Bengen, D.G.2002. Ekosistem dan Sumberdaya Alam Pesisir dan Laut serta 
Prinsip Pengelolaannya. Pusat Kajian Sumberdaya Pesisir dan Lautan IPB. Bogor.

Brown, K.T., Bender-Champ, D., Bryant, D.E., Dove, S., \& Hoegh-Guldberg, O. 2017. Human activities influence benthic community structure and the composition of the coral-algal interactions in the central Maldives. J. Exp. Mar. Biol. Ecol. 497:33-40. DOI: 10.1016/j.jembe.2017.09.006

Edinger, E.N., Jompa, J., Limmon, G.V., Widjatmoko, W. \& Risk, M.J. 1998. Reef degradation and coral biodiversity in Indonesia: effects of landbased pollution, destructive fishing practices, and changes over time. Mar. Poll. Bull. 36:617630. DOI: 10.1016/S0025-326X(98)00047-2

English, S., William, C. \& Baker, V. 1994. Survey Manual of Tropical Marine Resources. Asean -Australian Marine Project. Australia. $112 \mathrm{hlm}$.

Fahcrul. 2007. Metode Sampling Bioekologi. Jakarta: Bumi Aksara.

Gomez, E.D. \& Yap, H.T. 1998 Monitoring Reef Condition , p 171-178. In R.A. Kenchington and B.E.T. Hudson (Eds). Coral Reef Management Handbook. Unesco Regional Office For Science and Technology for Southeast Asia. Jakarta

Hapsari, R.A., Wijaya, N. I., \& Winarso, G. 2017. Luasan Dan Sebaran Kondisi Terumbu Karang Di Perairan Kepulauan Seribu. Prosiding Seminar Nasional Kelautan XII. Universitas Hang Tuah

Lasagna, R., Guido, G., Taruffi, M., Morri, C., Bianchi, C.N., Parravicini, V. \& Lavorano, S. 2014. A new synthetic index to evaluate reef coral condition. Ecological Indicators 40:1-9.

Licuanan, W. Y., Robles, R., Dygico, M., Songco, A., \& van Woesik, R. (2017).
Coral benchmarks in the center of biodiversity. Mar. Poll. Bull.114(2):11351140. DOI : 10.1016/j.marpolbul.2016.10. 017

Prasetia I. 2012. Rekruitmen Karang di Kawasan Wisata Lovina. J. Sains dan Teknologi 1(2):61-72. DOI: 10.23887/jstundiksha.v $1 \mathrm{i} 2.6037$

Rauf, A. \& Yusuf, M. 2004. Studi Distribusi dan Kondisi Terumbu Karang dengan Menggunakan Teknologi Penginderaan Jauh di Kepulauan Spermonde, Sulawesi Selatan. IImu Kelautan. 9(2):74-81

Sutono, D. 2016. Hubungan Persentase Tutupan Karang Hidup dan Kelimpahan Ikan Karang di Perairan Taman Nasional Laut Wakatobi. J. Perikanan dan Kelautan. 6(2):169-176

Tonin, S. 2018. Economic value of marine biodiversity improvement in coralligenous habitats. Ecological Indicators. 85:11211132.

Umardiono, A., 2011 . Pengembangan Obyek Wisata Taman Nasional Laut Kepulauan Karimunjawa. Surabaya: Universitas Airlangga.

Wahyudin, Y. 2011. Karakteristik sumberdaya pesisir dan laut kawasan Teluk Palabuhanratu, Kabupaten Sukabumi, Jawa Barat. Bonorowo Wetlands. $1(01): 19-32$.

Wilkinson, C. 2008. Status of Coral Reefs of the World. Global Coral Reef Monitoring Network and Reef and Rainforest Research Center. Townsville, Australia. $296 \mathrm{p}$.

Yusuf, M. 2013. Kondisi Terumbu Karang dan Potensi Ikan di Perairan Taman Nasional Karimunjawa, Kabupaten Jepara. Bul. Oseano. Mar. 2:54-60. 